\title{
RESEARCH
}

Open Access

\section{Remote sensing, GIS and chemical analysis for assessment of environmental impacts on rising of groundwater around Kima Company, Aswan, Egypt}

Abd El-Hay A. Farrag ${ }^{1}$, Hanaa A. Megahed ${ }^{2 *}$ and Mahmoud H. Darwish ${ }^{3}$

\begin{abstract}
Background: Kima company is located east of the river Nile, $2.5 \mathrm{~km}$ south of Aswan City. The Quaternary sands and gravels represent the main groundwater aquifer in the area. It is mainly recharged from the river Nile seepage between the high and the old Aswan Dams. Some water seepage comes from the fish hatchery canal close to the area. The objective is to study the temporal-spatial development of the drainage ponds resulting from the rise of the groundwater level in line with the agricultural and urban development in and around the Kima plant area using chemical analysis and advanced technology (remote sensing and GIS techniques).
\end{abstract}

Results: Many wells were drilled and used to pump the groundwater in and south of the area, from which 15 wells that were used to feed Aswan city by drinking water were stopped since 2009. As result, the groundwater level rises and most of the wells of Kima company flooded. The groundwater quality deteriorated and some environmental changes in the surrounding area were detected. Monitoring and analysis of these changes are studied using remote sensing and GIS techniques. The results show an increase in both the surface water bodies (ponds) and urban areas.

Conclusions: Since 2009, 15 productive drinking water wells were ceased in the study area. It is the main reason which caused more rising of the groundwater level accompanied by increasing of its salinity. The study detected and calculated the area influenced by the groundwater seepage, urbanization, and the agricultural reclamation areas. The successive changes in these parameters throughout the period 2007-2017 are calculated. Rising groundwater levels are expected to be a chronic problem and will likely be a major issue for residential areas of Aswan city.

Keywords: Kima company, Aswan dams, Quaternary aquifer, Hatchery fish, Environmental changes, Remote sensing

\footnotetext{
* Correspondence: hanaanarss@yahoo.com

${ }^{2}$ National Authority for Remote Sensing and Space Sciences (NARSS), Assiut,

Egypt

Full list of author information is available at the end of the article
} 


\section{Background}

The main aim of this study examines the rise in the level of the groundwater in the Quaternary aquifer at Aswan city, Upper Egypt. The groundwater represents the main source of freshwater used for drinking purposes. The main source of drinking water at Aswan city comes from groundwater, and some of this water is recharged from the area under study. Since 1956, the Egyptian Chemical Industries (Kima) was constructed. It is a large organization for nitrogen fertilizer industry in Aswan, Egypt. About 40 production wells were drilled in and around the company to produce about $37,000 \mathrm{~m}^{3}$ daily (about 13,000,000 $\mathrm{m}^{3}$ annually), which are used for the electrolysis of water units, for water boiling, and in industrial cooling processes. Some wells were ceased due to increasing of its salinity, and some others were flooded since June 2009. Moreover, about 15 groundwater wells which were used for drinking purposes were stopped due to the bacteriological impact resulted from the fish hatchery project effects close to the area. So, the groundwater extraction decreased to about $25,000 \mathrm{~m}^{3}$ annually. Some environmental activities in the area such as reclamation for agriculture, urban expansion, and fish hatchery projects affected the groundwater situation in the area. Remote sensing and geographic information system (GIS) techniques are used for monitoring and assessing these environmental changes that are related to the groundwater situation in the area under investigation. Several studies have verified the significance of remote sensing in environmental monitoring and change assessment in southern Egypt (Hereher 2014).

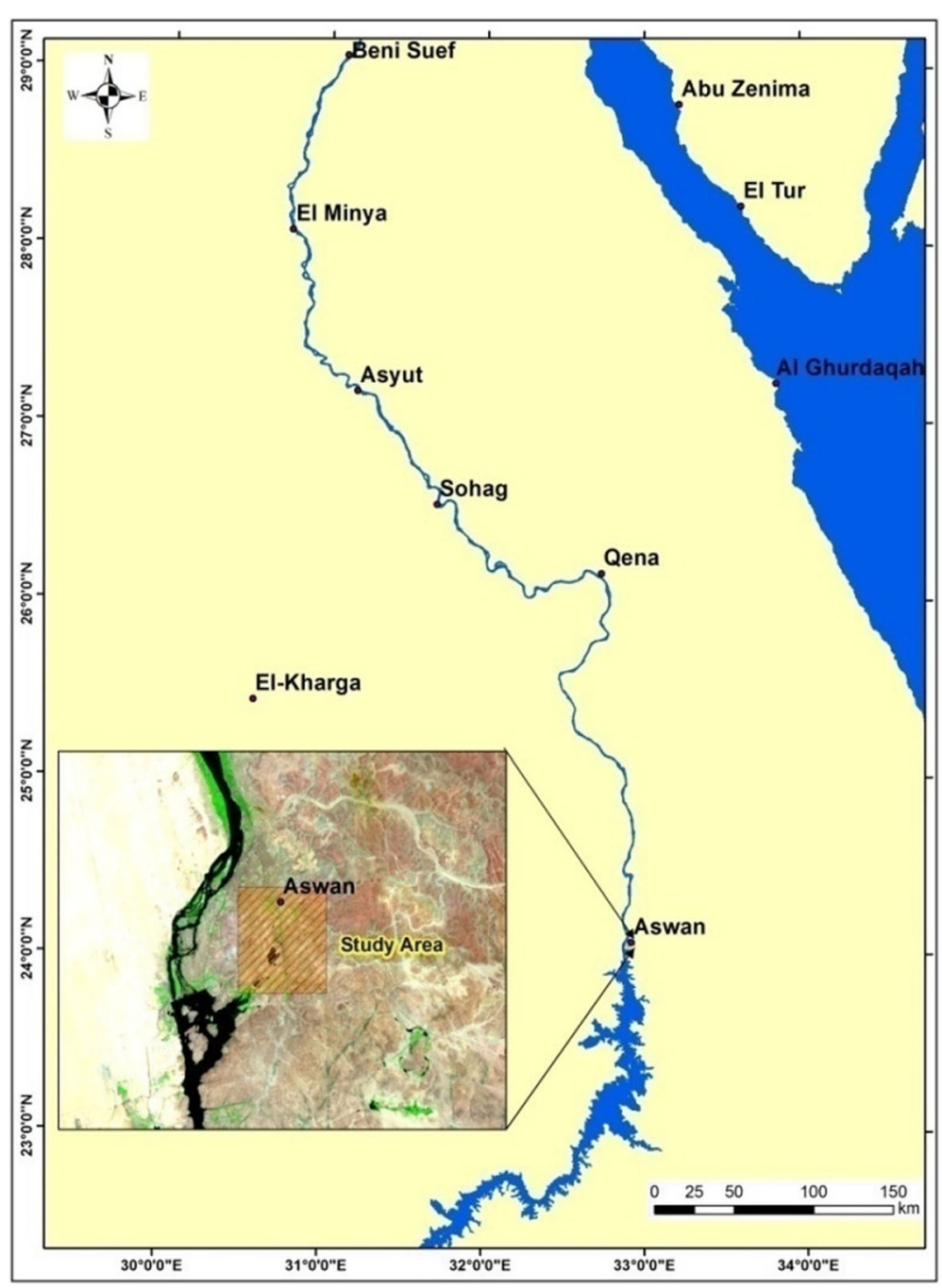

Fig. 1 Location map of the study area 


\section{Location of the study area}

Kima company area is located about $2.5 \mathrm{~km}$ to the south of Aswan city, about $5.0 \mathrm{~km}$ northeast of the Old Aswan Dam to the east of the Nile river (Fig. 1). There are sandy quarries south and west of the company. Mountain composed of sandstone and clay lies to its eastern side, while to the western side configurations of granite are found.

\section{Landforms and geological features}

Geomorphologically, the study area slopes gently from the southwestern side to northeastern side with elevation varying from about +122.5 to about $+116.5 \mathrm{~m}$ (locally $+114.5 \mathrm{~m}$ ). A large depression (a former sand quarry) approximately $20-\mathrm{m}$ deep is present south and west of the Kima company. The area of study is surrounded by highland from the east and west sides with extensive bounds from the eastern side. Basement complex and Nubian Sandstone rocks represent the highlands of these sides.

Geologically, the area under investigation is located within an abandoned Nile river channel consisting of fluvial deposits denoted as "Quaternary" in the schematic geological map shown in (Fig. 2). The Quaternary sediments are composed of sands, gravels, and clays of the Pleistocene time and mud with eolian sediments of recent time overlain in a thick bed of Pliocene clays (RIGW 1988). The area is bounded from the east and west sides by complex Precambrian rocks of igneous and metamorphic rocks mainly of granites and schists. Unconformable Nubian Sandstone overlay the basement rocks with thickness ranging between 20 and $85 \mathrm{~m}$ (Attia 1954).

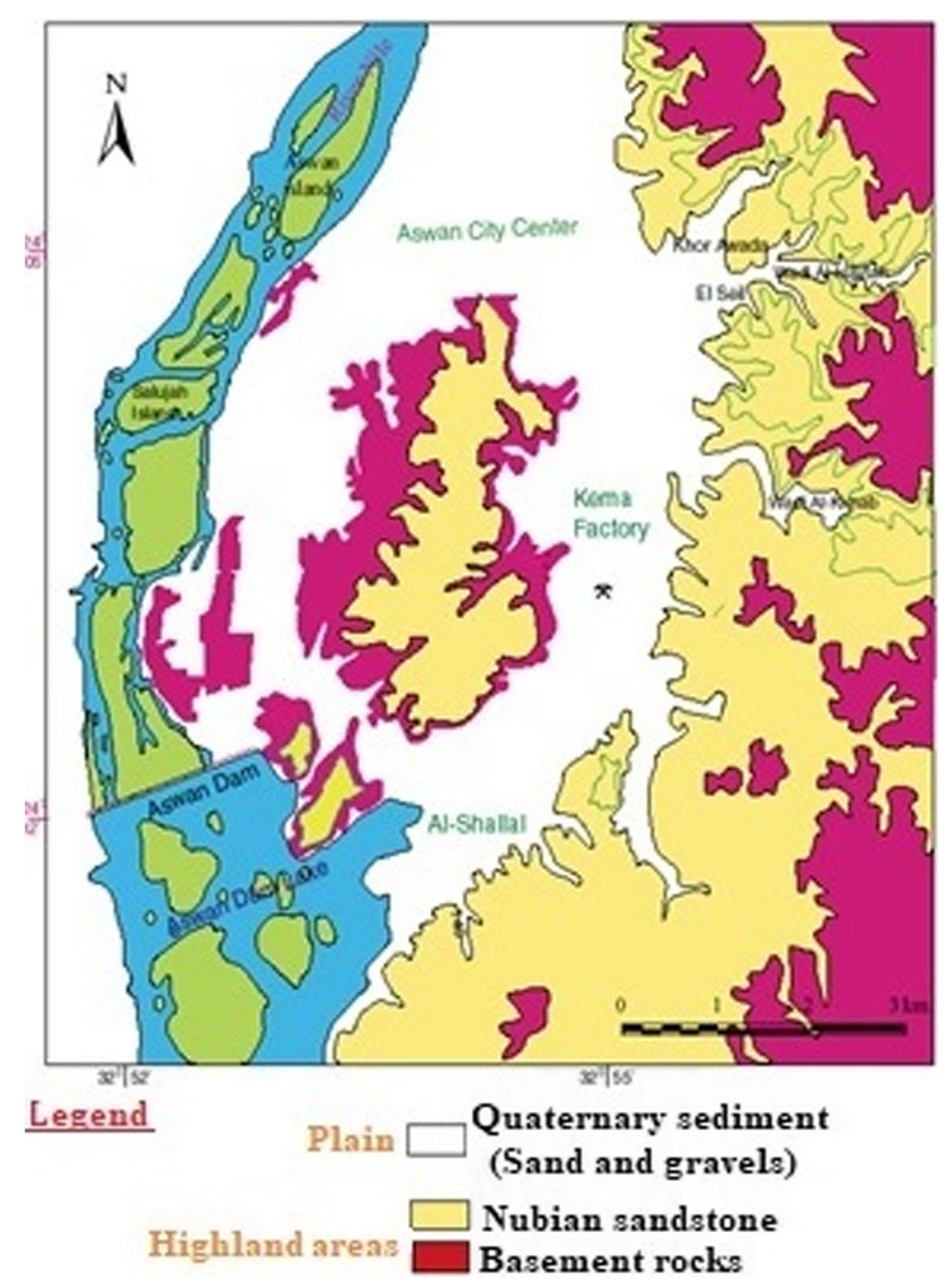

Fig. 2 Geological map of the study area (modified after Egyptian Geological Survey, 1985) 


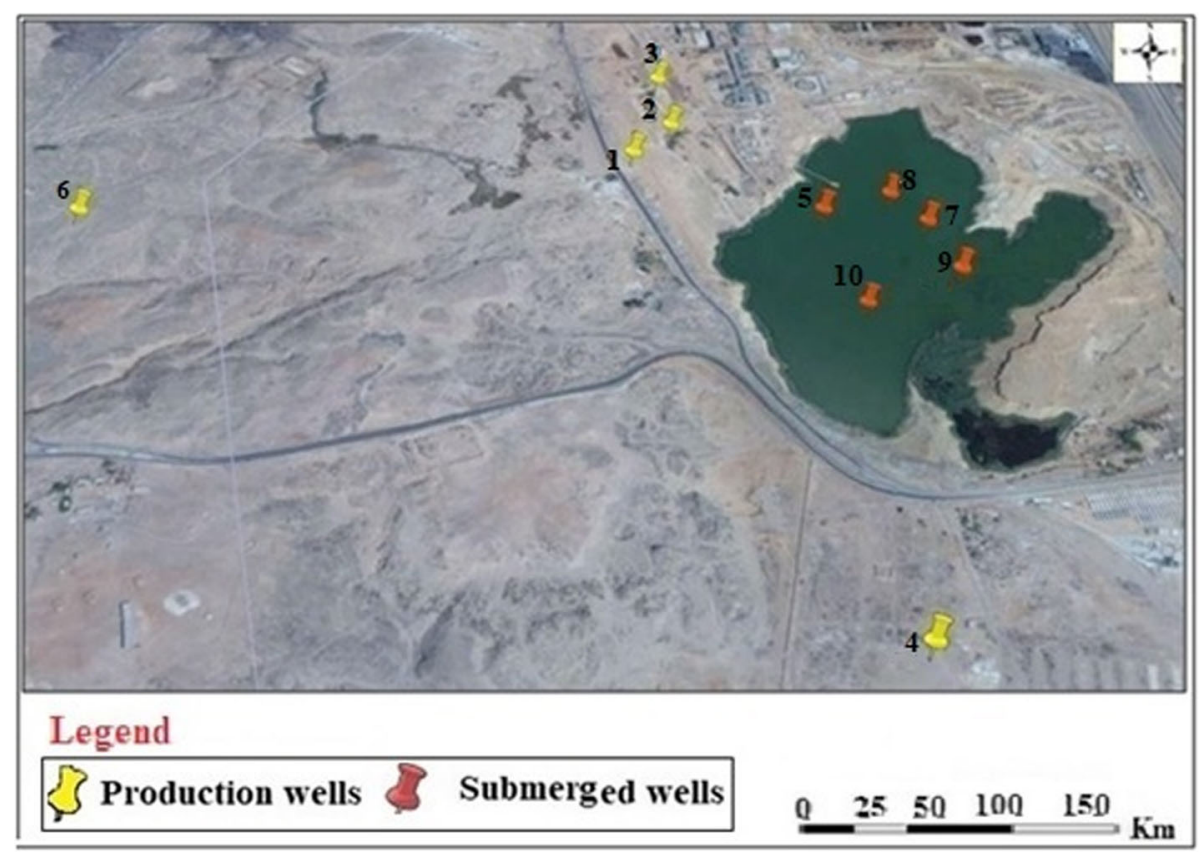

Fig. 3 Location of the groundwater wells (production and submerged wells after 2009)

\section{Methods}

Some groundwater samples have been collected from the study area (Fig. 3). Their physical and chemical characteristics were determined during the three periods (2007, 2013, and 2017). Analysis for different physiochemical parameters (TDS, pH, TA, TH), major cations $\left(\mathrm{Ca}^{2+}, \mathrm{Mg}^{2+}, \mathrm{Na}^{+}, \mathrm{K}^{+}\right)$, major anions $\left(\mathrm{Cl}^{-}\right)$, and some trace ions $\left(\mathrm{NO}^{2}, \mathrm{SiO}^{2}\right)$ was carried out (Table 1). Samples were collected in polyethylene bottles $(1 \mathrm{~L})$ after $10 \mathrm{~min}$ of pumping to avoid any local contamination or evaporation. The physical and chemical parameters were estimated and measured including turbidity, total dissolved solids (TDS), hydrogen ion concentrations $(\mathrm{pH})$, and the concentrations of the major ions (sodium $\left(\mathrm{Na}^{+}\right)$, potassium $\left(\mathrm{K}^{+}\right)$, calcium $\left(\mathrm{Ca}^{2+}\right)$, magnesium $\left(\mathrm{Mg}^{2+}\right)$, and chloride $\left.\left(\mathrm{Cl}^{-}\right)\right)$. The chemical analyses were carried out in the Laboratory of the Faculty of Agriculture, Assiut University. Electrical conductivity measurements were used to estimate the total dissolved solids (TDS). $\mathrm{Ca}^{2+}$ and $\mathrm{Mg}^{2+}$ were determined using the titration with standard versenate (EDTA) solution, using Eriochrome Black $\mathrm{T}$ (EBT) as an indicator. $\mathrm{Na}^{+}$and $\mathrm{K}^{+}$were determined using flame photometry method. Chloride $\left(\mathrm{Cl}^{-}\right)$was determined using the standard solution of silver nitrate and nitrate, and silica contents were measured using spectrophotometry method.
Three temporal images from different Landsat sensors have been applied. Those are Landsat TM image acquired in 2007, ETM+ image acquired in 2013, and Landsat 8 image acquired in 2017 (Fig. 4). Producing of the used data have been accomplished for more accurate results, including atmospheric correction, resolution merge, and subset function. Super- and unsupervised classification techniques were used to delineate the water zones, urban areas, and agriculture areas. Accordingly, the environmental changes are detected. Several studies have verified the significance of multitemporal Landsat TM/ETM+ data in land use and change detection studies (Kaufman and Seto 2001; Helmschor and Fliigel 2002; Green et al. 1994). Although the accuracy of the resulted change maps is subjected to error propagation and depending on the accuracy of the input classification maps, the individual classified images constitute a historical series that can be used in applications other than change detection (Yuan et al. 2005). The analysis then identifies the classes by associating a sample of pixels in unsupervised classification and is therefore useful for determining the spectral class composition of the data prior to detail by the methods of supervised classification (Nagy and Toloba 1971 and Das 1990). Change detection involves the ability to quantify temporal changes in land use and land cover using multi-temporal data sets (Singh 1989; Ridd and Liu 
Table 1 Results of the physical and chemical analysis of some groundwater samples

\begin{tabular}{|c|c|c|c|c|c|c|c|c|c|c|}
\hline \multirow{2}{*}{$\begin{array}{l}\text { Well } \\
\text { number }\end{array}$} & \multicolumn{4}{|c|}{ Physio-chemical parameters } & \multicolumn{4}{|c|}{ Major cations (ppm) } & \multirow{2}{*}{$\begin{array}{l}\text { Major anions (ppm) } \\
\mathrm{Cl}\end{array}$} & \multirow{2}{*}{$\begin{array}{l}\text { Trace ions (ppm) } \\
\mathrm{NO}_{2}\end{array}$} \\
\hline & $\mathrm{pH}$ & TA (ppm) & TH (ppm) & TDS (ppm) & $\mathrm{Ca}$ & $\mathrm{Mg}$ & $\mathrm{Na}$ & K & & \\
\hline \multicolumn{11}{|c|}{ Year 1990} \\
\hline 1 & 7.61 & 180 & 168 & 329 & 48.8 & 11 & 25.5 & 2.2 & 7.1 & 0.042 \\
\hline 2 & 7.98 & 200 & 176 & 384 & 45.6 & 14.88 & 20 & 2.2 & 3.48 & 0.04 \\
\hline 3 & 7.87 & 200 & 162 & 316 & 46.4 & 11.04 & 28 & 3 & 3.55 & 0.005 \\
\hline 4 & 7.6 & 150 & 138 & 220 & 40 & 9.12 & 32 & 2.3 & 7.1 & 0.001 \\
\hline 5 & 7.26 & 180 & 162 & 240 & 46.4 & 11.04 & 35 & 6 & 3.55 & 0.055 \\
\hline 6 & 7.8 & 150 & 148 & 210 & 44.8 & 8.64 & 30 & 3 & 3.55 & 0.02 \\
\hline 7 & 7.6 & 140 & 148 & 220 & 44.8 & 8.64 & 38 & 5 & 3.55 & 0.0001 \\
\hline 8 & 7.8 & 110 & 92 & 170 & 25.5 & 6.72 & 30 & 3.2 & 3.55 & 0.01 \\
\hline 9 & 7.22 & 150 & 132 & 230 & 37.2 & 9.36 & 32 & 4 & 12.3 & 0.042 \\
\hline 10 & 7.6 & 170 & 174 & 299 & 49.6 & 11 & 28 & 2.6 & 3.55 & 0.04 \\
\hline \multicolumn{11}{|c|}{ Year 2000} \\
\hline 1 & 7.88 & 190 & 170 & 339 & 50.4 & 10.56 & 30 & 3 & 28.4 & 0.026 \\
\hline 2 & 7.9 & 170 & 202 & 445 & 52 & 17.28 & 31.5 & 2.3 & 35.8 & 0.027 \\
\hline 3 & 8.23 & 170 & 340 & 769 & 96.8 & 23.52 & 38 & 5 & 106.5 & 0.021 \\
\hline 4 & 7.33 & 170 & 204 & 293 & 56 & 15.36 & 32 & 2.4 & 3.55 & 0.0008 \\
\hline 5 & 7.21 & 200 & 120 & 265 & 34.4 & 8.16 & 28 & 3 & 3.55 & 0.017 \\
\hline 6 & 7.33 & 190 & 138 & 213 & 36.8 & 11.04 & 30 & 3 & 14.2 & 0.011 \\
\hline 7 & 7.49 & 150 & 162 & 213 & 43.2 & 12.96 & 38 & 5 & 10.65 & 0.02 \\
\hline 8 & 7.19 & 175 & 150 & 240 & 37.5 & 13.44 & 30 & 3.2 & 21.3 & 0.009 \\
\hline 9 & 8 & 170 & 168 & 230 & 42.8 & 14.64 & 32 & 4 & 21.3 & 0.006 \\
\hline 10 & 8.06 & 190 & 174 & 299 & 49.6 & 12 & 28 & 2.6 & 7.1 & 0.02 \\
\hline \multicolumn{11}{|c|}{ Year 2010} \\
\hline 1 & 7.94 & 200 & 158 & 387 & 44 & 11.52 & 25.5 & 2.2 & 7.1 & 0.036 \\
\hline 2 & 8.29 & 106.5 & 170 & 484 & 47.2 & 12.48 & 20 & 2.2 & 10.65 & 0.004 \\
\hline 3 & 7.72 & 190 & 166 & 500 & 46.4 & 12 & 28 & 3 & 21.3 & 0.009 \\
\hline 4 & 7.42 & 170 & 620 & 990 & 160 & 52.8 & 32 & 2.3 & 160 & 0.4 \\
\hline 5 & \multicolumn{10}{|c|}{ Submerged } \\
\hline 6 & 7.68 & 200 & 204 & 355 & 57.6 & 14.4 & 30 & 3 & 28.4 & 0.103 \\
\hline 7 & \multicolumn{10}{|c|}{ Submerged } \\
\hline 8 & \multicolumn{10}{|c|}{ Submerged } \\
\hline 9 & \multicolumn{10}{|c|}{ Submerged } \\
\hline 10 & \multicolumn{10}{|c|}{ Submerged } \\
\hline
\end{tabular}

1998). During the past three decades, many change detection algorithms have been developed, and they vary widely in their sophistication and performance (Collins and Woodcock 1996; Ola and Hay 2003).

\section{Results}

\section{Hydrogeology}

Chemical analysis of the groundwater

The results of the groundwater analysis of the ten wells during three periods (2007, 2013, and 2017) are shown in Table 1. A slight increase in TDS content can be observed in some wells. Calcium and magnesium represent the dominated cations, while bicarbonate and chloride are the dominated anions $\left(\mathrm{Ca}>\mathrm{Mg}\right.$ and $\mathrm{HCO}_{3}>\mathrm{Cl}$ ). A slight fluctuation in $\mathrm{pH}$ and alkalinity values can be noticed. The groundwater ranged between moderately hard to very hard water (Fig. 5). The nitrite $\left(\mathrm{NO}_{2}\right)$ occurred by bacterial action and contamination from Kima factory; the concentration ranges between 0.0001 and $0.01 \mathrm{ppm}$. 


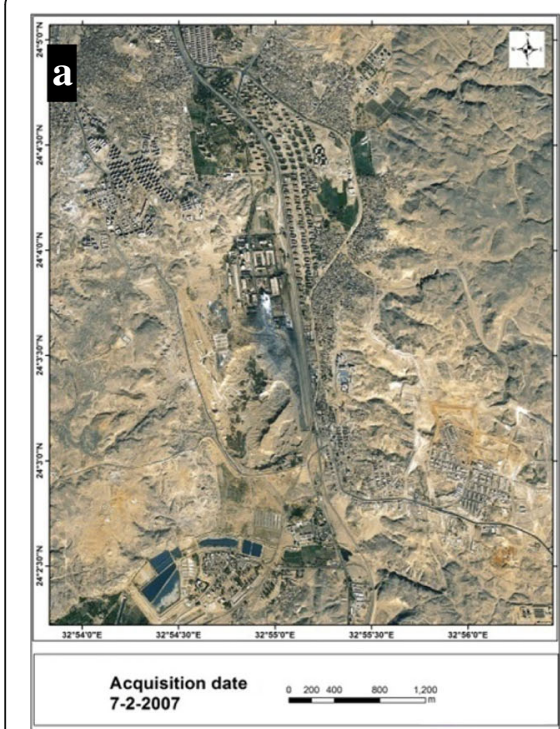

OverView Image 2007

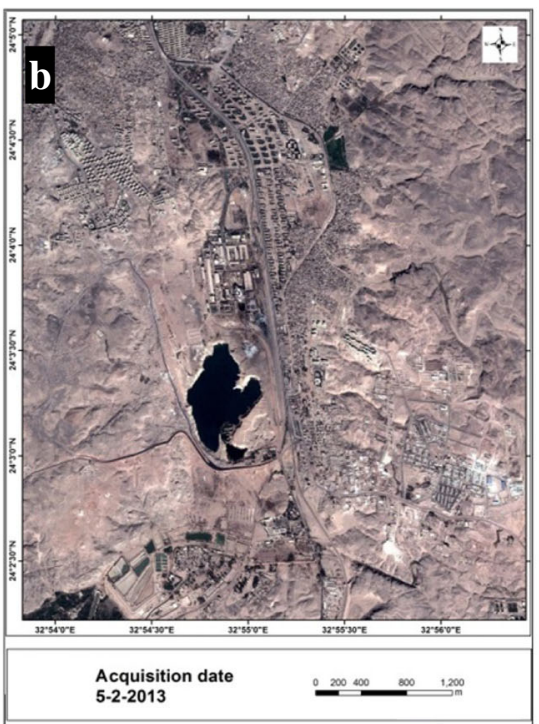

OverView Image 2013

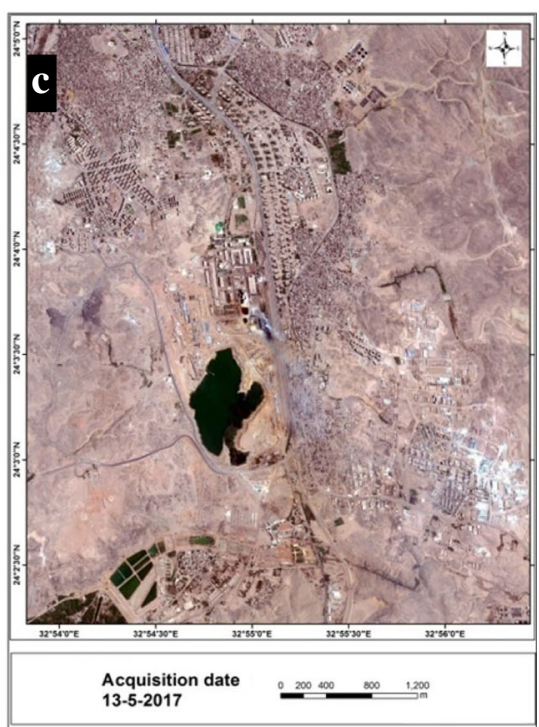

OverView Image 2017

Fig. 4 Landsat images detect the environmental changes in the study area, a Overview Image 2007, b Overview Image 2013 and c Overview Image 2017

These changes in the groundwater quality and composition are mainly attributed to the reclamation processes in addition to the effects of the water seepage from the unsealed fishing hatchery basins project (Fig. 6).

\section{Groundwater level change}

The direction of the groundwater movement is generally from south to north due to the steepening of the slope of the groundwater in the highland areas in the southern part. Continuous rising in the water table in the area since June 2009 is detected (Figs. 7 and 8a, b). In some wells, the water table rose about $14 \mathrm{~m}$. Moreover, Kima Pond was formed, and thus, some wells were submerged.

\section{Change detection of the environmental impacts}

Change detection involves the ability to quantify spatio-temporal changes in water ponds, agriculture areas, and urban areas using multi-temporal datasets using Landsat satellite images during the period of 2007-2017. These environmental changes have a bad impact on the area and also causing the rise in groundwater level.

The maximum likelihood classifier was used to perform the supervised classification. Post-classification refinement of the resulting classified images was applied to the inaccurately classified pixels to increase the overall accuracy of the resulting land cover maps. The final products of the hybrid classification were three land cover maps in which the spatial distribution of the land cover classes are for the years 2007, 2013, and 2017 (Fig. 9).

Spatio-temporal changes in different land cover classes, which were monitored in the whole area during the study periods, are shown in Figs. 10, 11, and 12. Change results confirmed a gradual increase in the extent of the surface waters bodies in the area as a result of the increasing of groundwater levels and an increase of vegetation cover and urban areas (Table 2 and Fig. 13).

\section{Discussion}

The Quaternary aquifer in Aswan, Egypt, is the most important aquifer in the area; it is composed of few cohesion layers of recent sediments of high porosity consisting of sand and gravel with fine silt with maximum thickness in the study area of about 100 to $120 \mathrm{~m}$ (Fig. 14). Mud and silt represent the top of the aquifer while the bottom is bounded by the Pliocene mud, which extends to more than $240 \mathrm{~m}$ depth. The direction and speed of groundwater flow changes from one area to another within the quaternary aquifer but it is mainly from north to northwest (Fig. 15).

The main groundwater sources are from the confinement area between the High Dam and Aswan Dam and the canals from the fish hatchery region where the surface water level reaches up to the $116 \mathrm{~m}$ above sea level. 


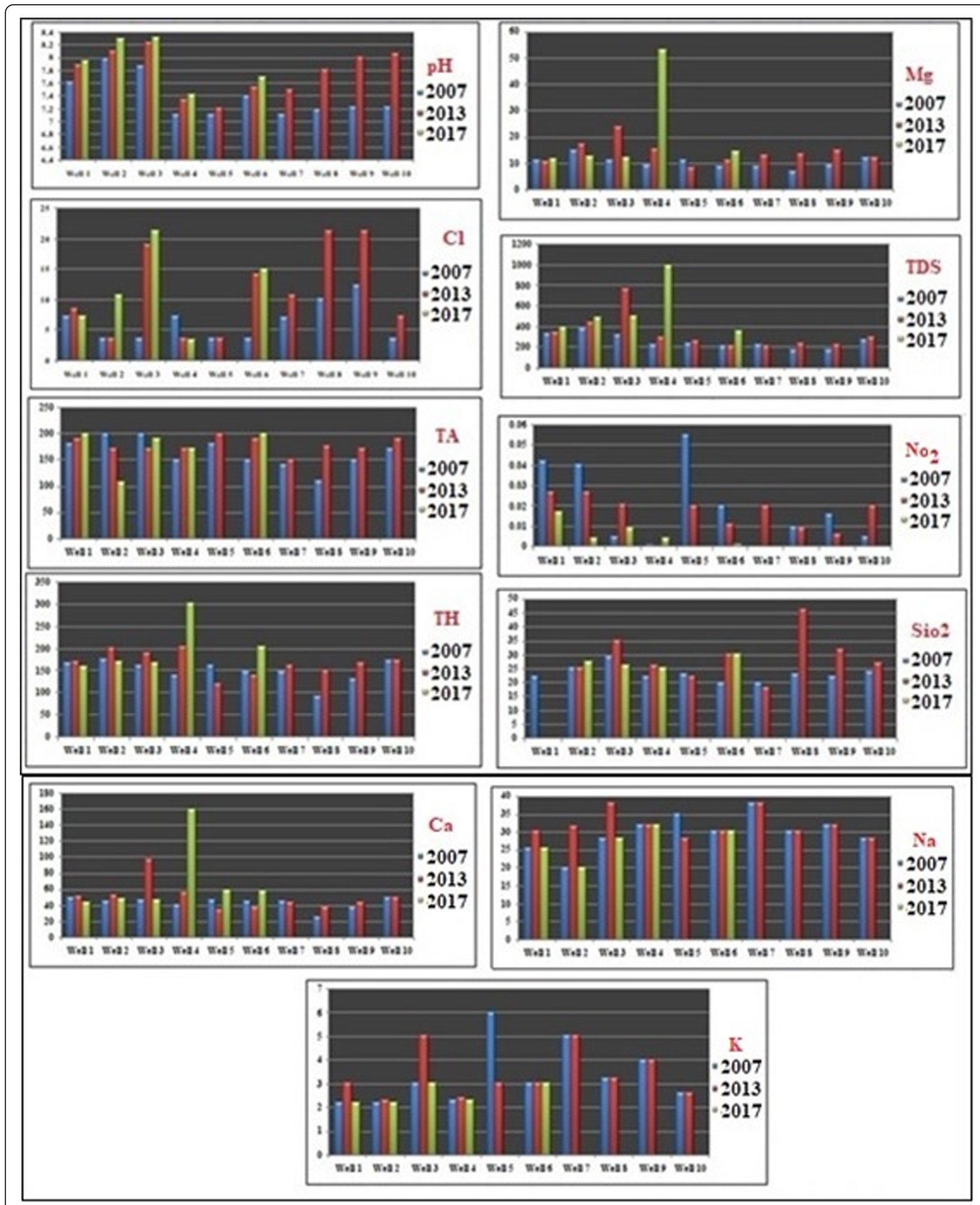

Fig. 5 Bar diagrams show the variations in the groundwater composition during the periods (1990-2010) 


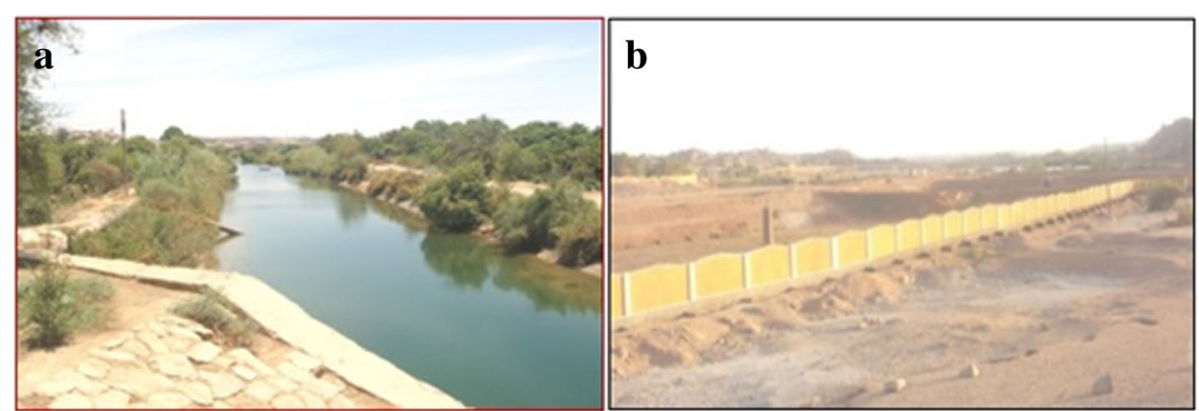

Fig. 6 Water seepage from the unsealed fishing hatchery basins project in a kima area, b sand quarry

The phenomenon of rising of the groundwater level in Kima wells began in June 2009 by the appearance of wet sand (moistened) surrounding a number of wells. By the time the wet sands became more saturated and covered by water is the same time of the closure of 15 wells, owing to the discharging for Aswan drinking and the contamination by a sewage water company. It had the greatest impact on increasing the static water level in Kima wells.

During the last two decades, some fish hatcheries were constructed to the south of the area and affected the groundwater quality. An increase in the groundwater levels dominated the area where the quarry depression flooded and some wells immerged

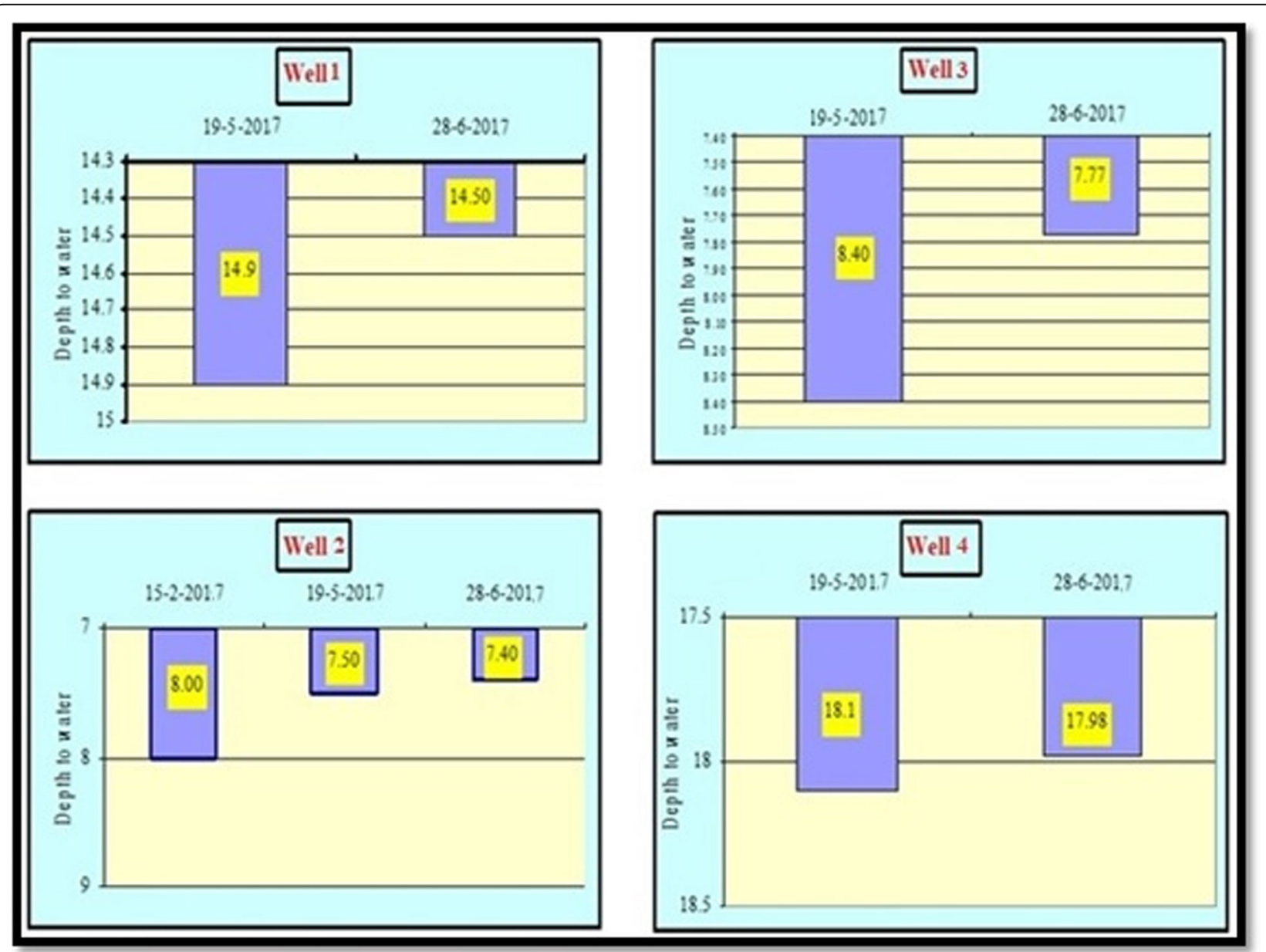

Fig. 7 Changes in the groundwater depth in some wells with time 

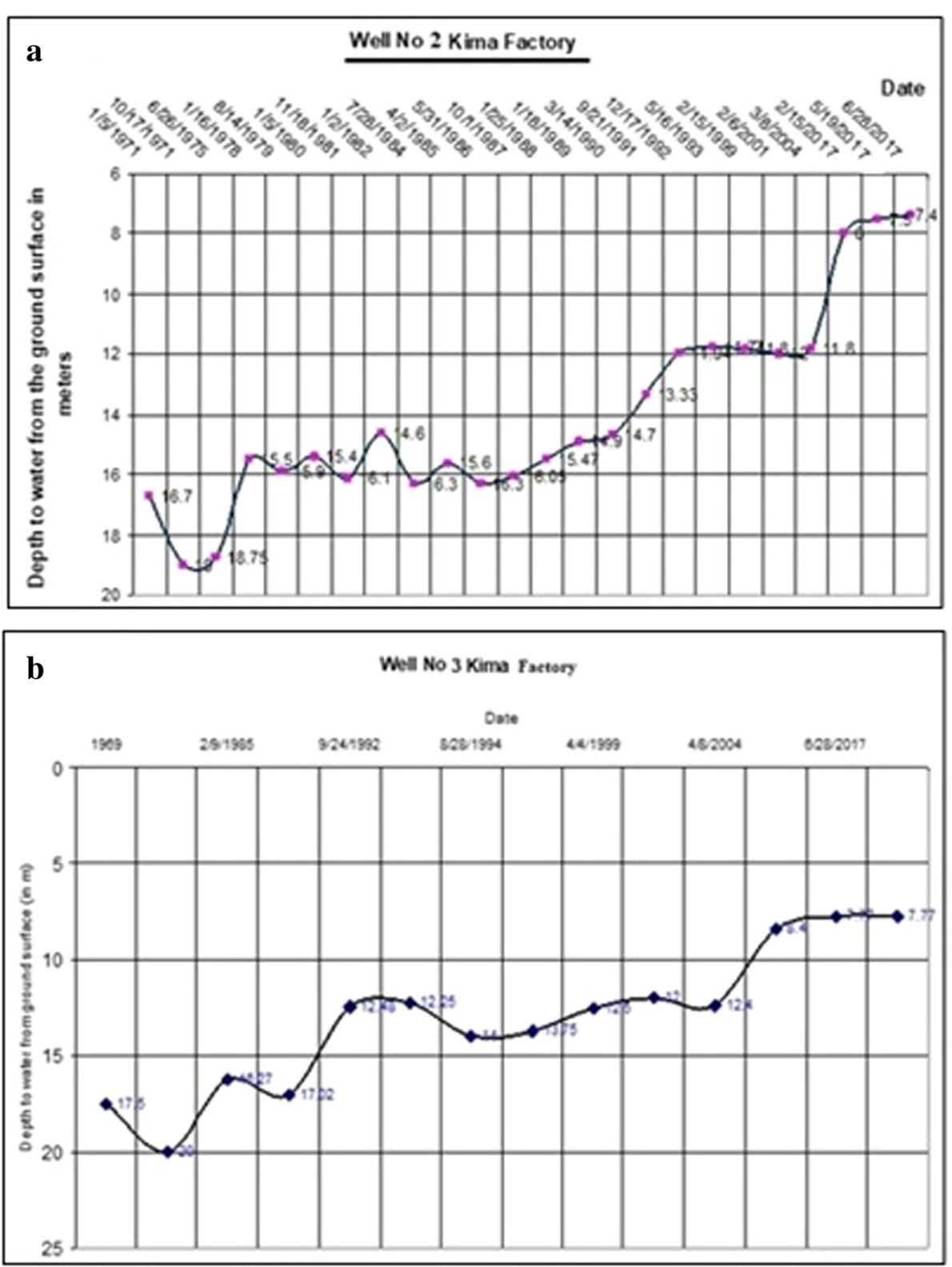

Fig. 8 a, b Groundwater level change with time in well no.2 and well no.3

(Fig. 16). Some environmental changes and activities happened and are related to that change in the groundwater situation and quality. Practical thinking to exploit the waters from the sand quarry had been made by the installation of four submersible pumps in the lake to supply Kima plant with water. In 2015, a floating pump station had been installed to fulfill the shortfall in water needs.

Field observations and advanced technology (Landsat images and GIS techniques) were freely available at National Authority for Remote Sensing and Space Sciences (NARSS). Land cover/land use and change detection maps were obtained and correlated with the groundwater situation. Change detection maps for the water ponds, agriculture areas, urban expansion, and fish hatchery projects were constructed by the use of Landsat images acquired on 2007, 2013, and 2017 for the study area which were presented and classified using supervised techniques.

The obtained change detection maps showed that the groundwater situation in the area was affected by such 


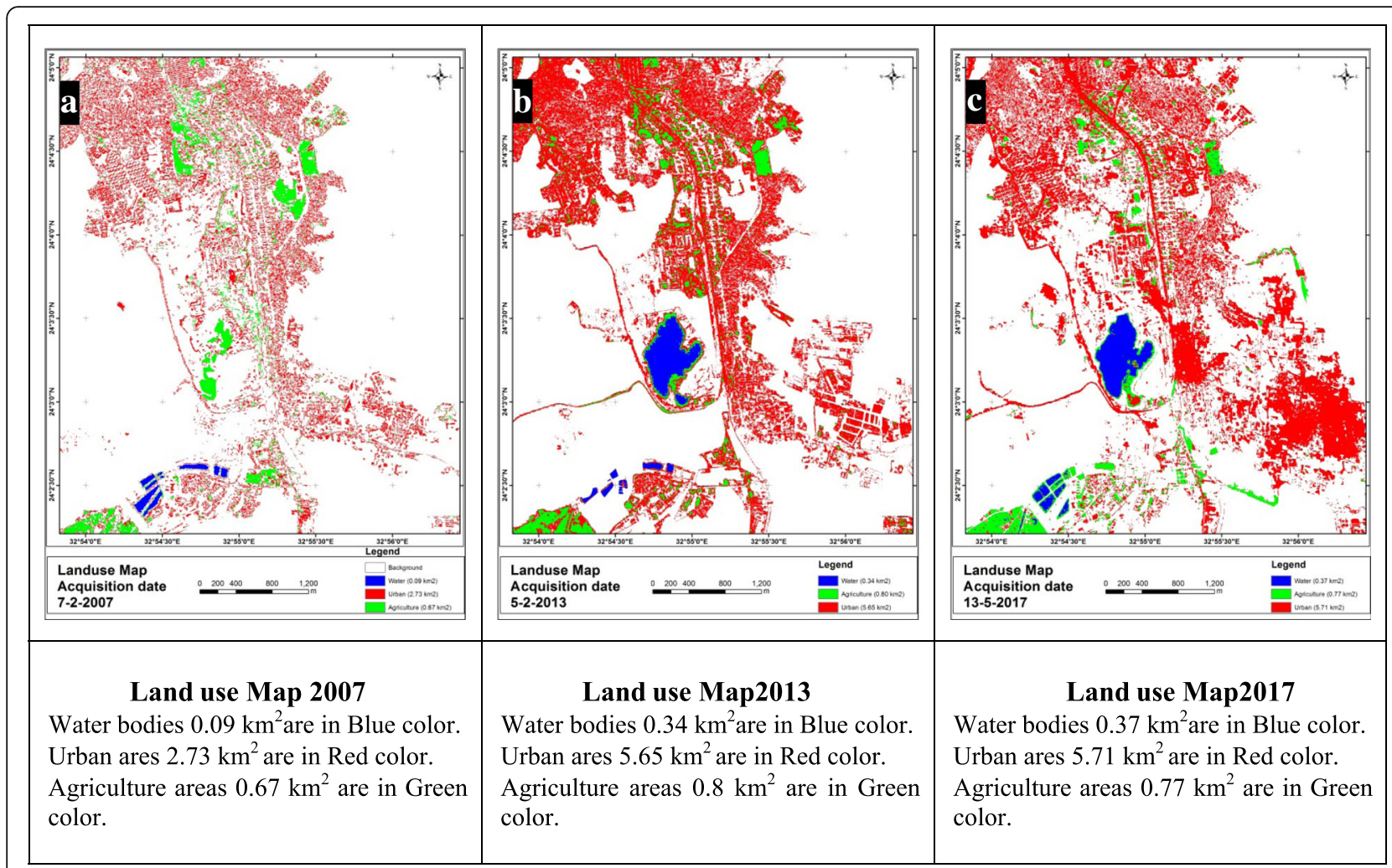

Fig. 9 General Landuse changes and detections during the period 2007-2017 a Landuse Map 2007, b Landuse Map2013 and c Landuse Map2017

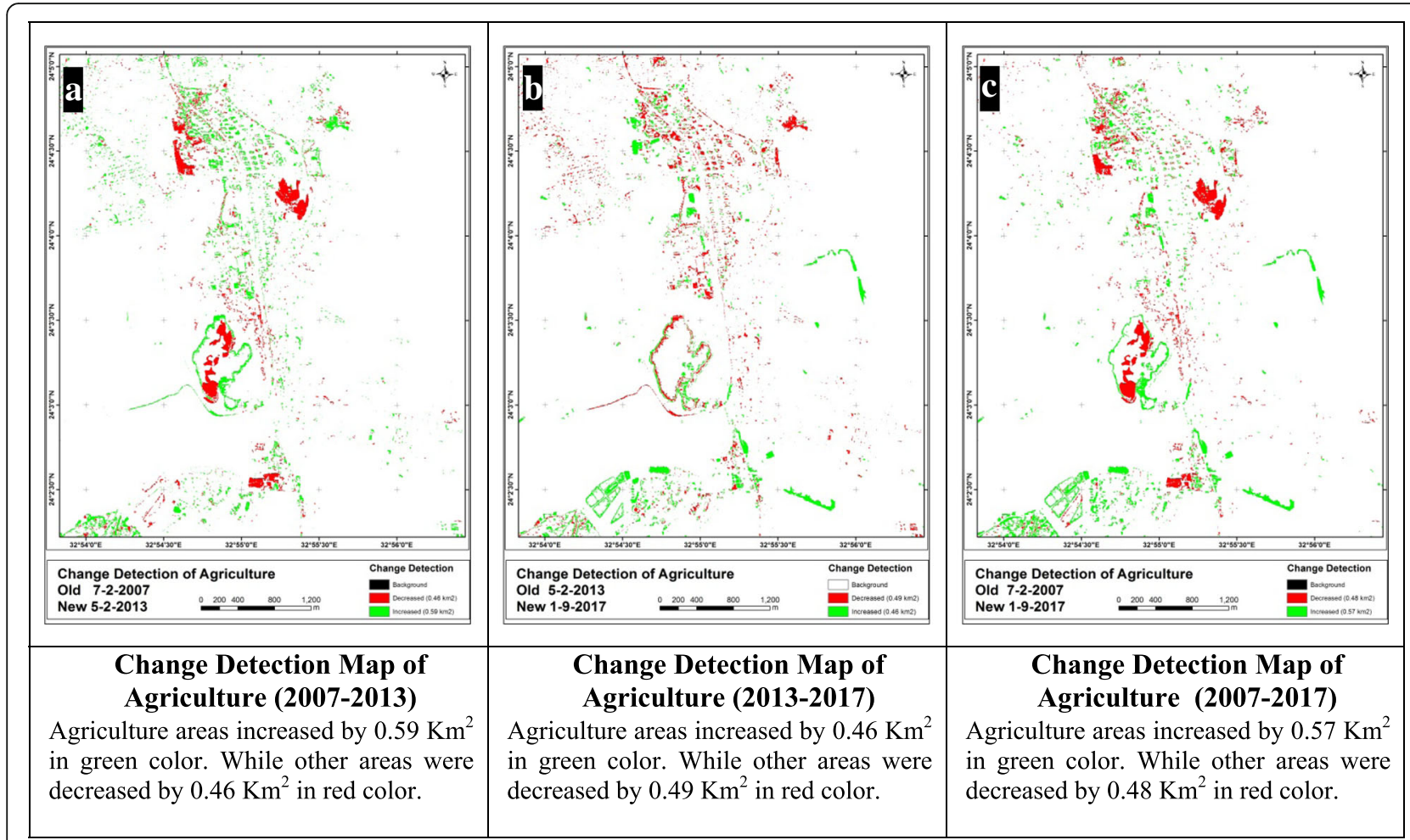

Fig. 10 Change detections of agriculture areas during the period of 2007-2017 in study area a Change Detection Map of Agriculture (2007-2013), b Change Detection Map of Agriculture (2013-2017) and c Change Detection Map of Agriculture (2007-2017) 


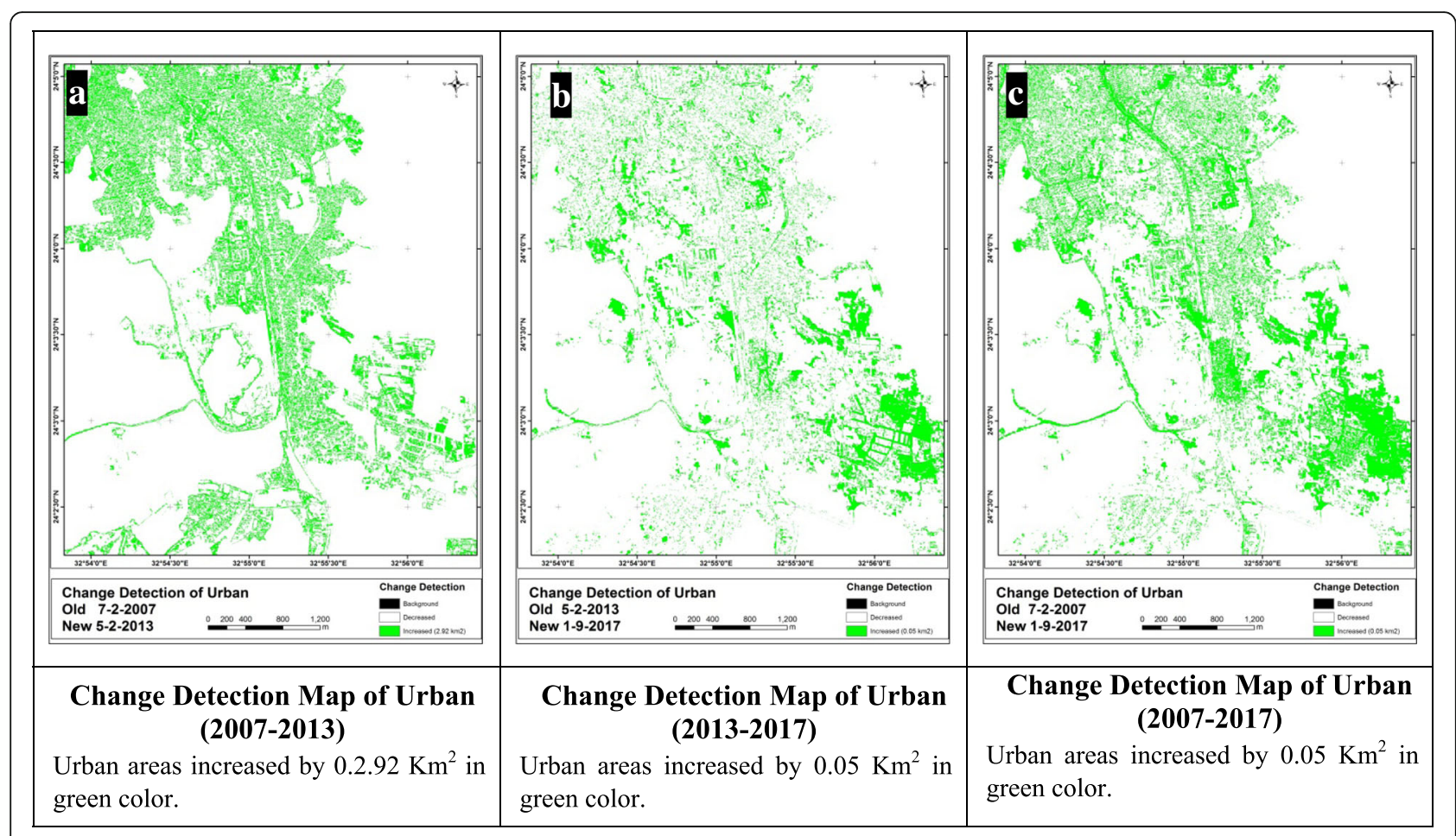

Fig. 11 Change detections in urban areas through the period 1987-2014 in the study area a Change Detection Map of Urban (2007-2013), b Change Detection Map of Urban (2013-2017) and c Change Detection Map of Urban (2007-2017)

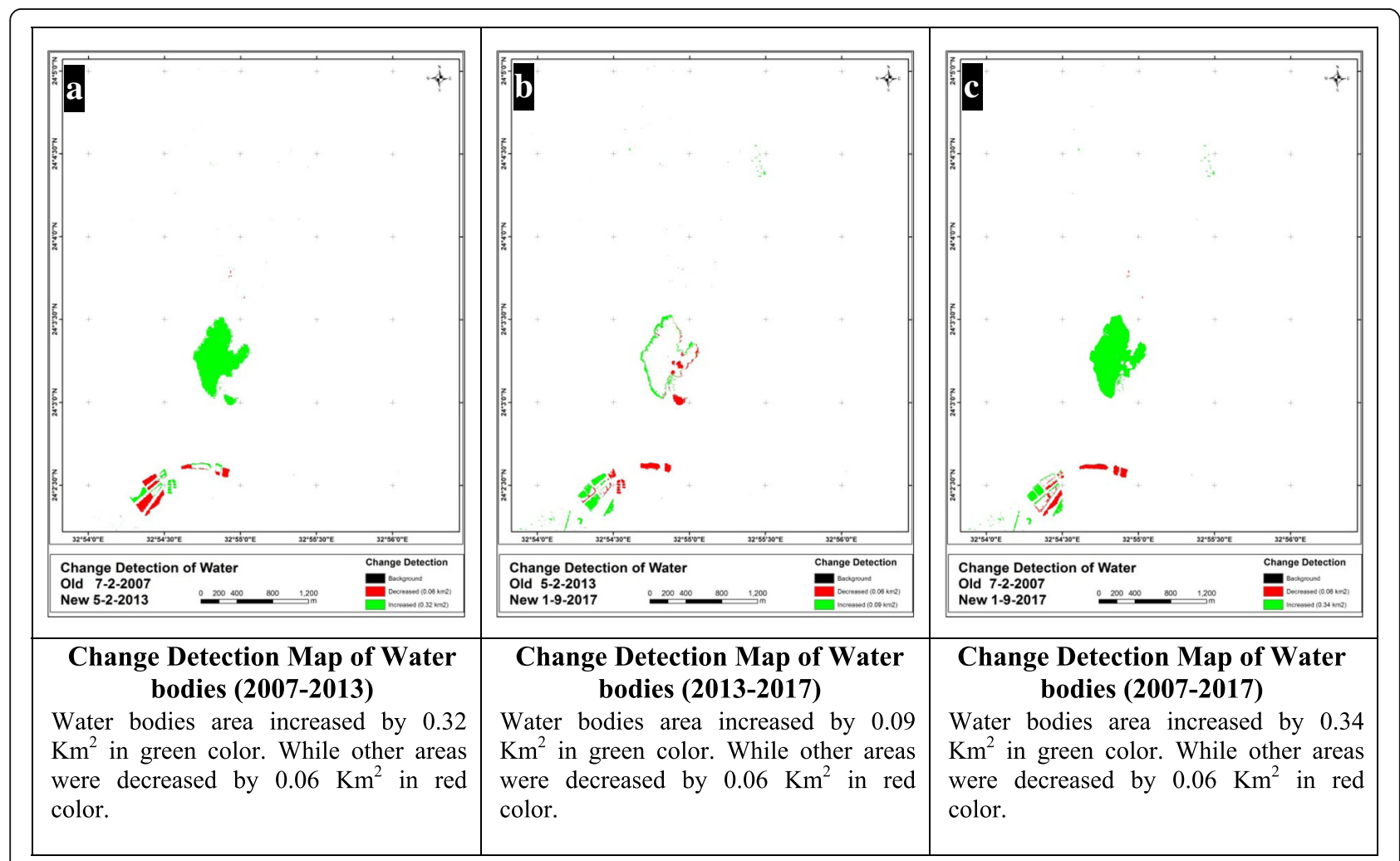

Fig. 12 Change detection of water bodies during the period of 2007-2017 in the study area a Change Detection Map of Water bodies (20072013), b Change Detection Map of Water bodies (2013-2017) and c Change Detection Map of Water bodies (2007-2017) 
Table 2 Change detection of land cover classes $\left(\mathrm{km}^{2}\right)$ monitored in the 2007-2017 periods in the study area

\begin{tabular}{|c|c|c|c|c|c|c|}
\hline $\begin{array}{l}\text { Years } \\
\text { Land } \\
\text { cover classes }\end{array}$ & Area/km² (2007) & $\begin{array}{l}\text { Area } / \mathrm{km}^{2} \\
(2013)\end{array}$ & $\begin{array}{l}\text { Area } / \mathrm{km}^{2} \\
(2017)\end{array}$ & $\begin{array}{l}\text { 2007/2013 } \\
\text { changes }\end{array}$ & $\begin{array}{l}\text { 2013/2017 } \\
\text { changes }\end{array}$ & $\begin{array}{l}\text { 2007/2017 } \\
\text { changes }\end{array}$ \\
\hline Water bodies & 0.09 & 0.34 & 0.37 & $\begin{array}{l}0.06 \text { (decrease) } \\
0.32 \text { (increase) }\end{array}$ & $\begin{array}{l}0.06 \text { (decrease) } \\
0.09 \text { (increase) }\end{array}$ & $\begin{array}{l}0.06 \text { (decrease) } \\
0.34 \text { (increase) }\end{array}$ \\
\hline Urban & 2.73 & 5.65 & 5.71 & $\begin{array}{l}0.00 \text { (decrease) } \\
2.92 \text { (increase) }\end{array}$ & $\begin{array}{l}0.00 \text { (decrease) } \\
0.05 \text { (increase) }\end{array}$ & $\begin{array}{l}0.00 \text { (decrease) } \\
2.97 \text { (increase) }\end{array}$ \\
\hline Agriculture & 0.67 & 0.80 & 0.77 & $\begin{array}{l}0.46 \text { (decrease) } \\
0.59 \text { (increase) }\end{array}$ & $\begin{array}{l}0.49 \text { (decrease) } \\
0.06 \text { (increase) }\end{array}$ & $\begin{array}{l}0.48 \text { (decrease) } \\
0.57 \text { (increase) }\end{array}$ \\
\hline
\end{tabular}

changes; as the change detection analysis results show a systematic increase in agricultural activities between 2007 and 2017 resulting from national agricultural development plans by about $0.57 \mathrm{~km}^{2}$, water ponds area also increased by about $0.34 \mathrm{~km}^{2}$ during the same period, and the increase in urbanization by $2.97 \mathrm{~km}^{2}$ was attributed predominantly to encroachment into traditionally cultivated land.

Our result accurately quantifies the environmental changes and delineates their spatial patterns, demonstrating the utility of Landsat data in analyzing landscape dynamics over time.

\section{Conclusions}

The Quaternary water-bearing sediments represent the main groundwater aquifer in the area around Kima company, Aswan Governorate. It is recharged locally from the water seeped from lake Nasser, excess irrigation water, and from the unsealed fish hatchery basins. On the other hand, the groundwater is either discharged back to the river Nile, north of the Aswan Dam, or accumulated in the area causing a local rise of its level and formation of water ponds in the depressions and lowland localities. Since 2009, 15 productive drinking water wells were stopped as a result of their bacterial contaminations.

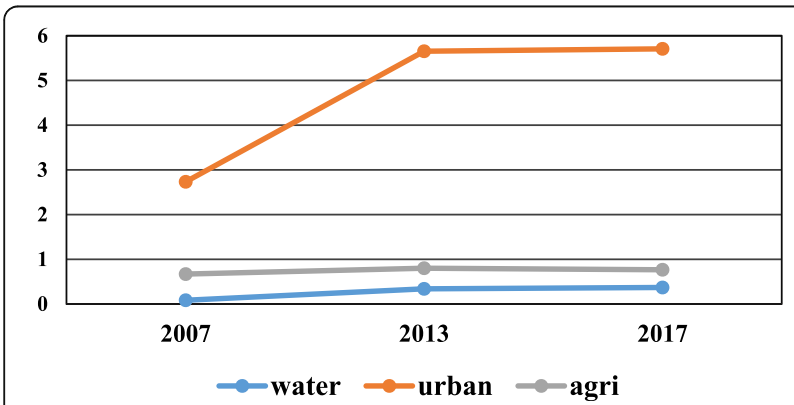

Fig. 13 Diagrams showing temporal changes in different land cover classes in the study area
It is the main reason which caused more rising of the groundwater level accompanied by the increase of its salinity. The study detected and calculated the area influenced by the groundwater seepage, urbanization, and the agricultural reclamation areas. The successive changes in these parameters throughout the period 2007-2017 are calculated.

To avoid the problem caused by groundwater level rising and contamination, it is recommended to:

Use spring and/or drip irrigation system instead of flooding irrigation method

Apply good drainage system to decrease the groundwater levels in the area

Seal well the fish hatchery basins to prevent the main cause of bacterial contamination of the groundwater in the area
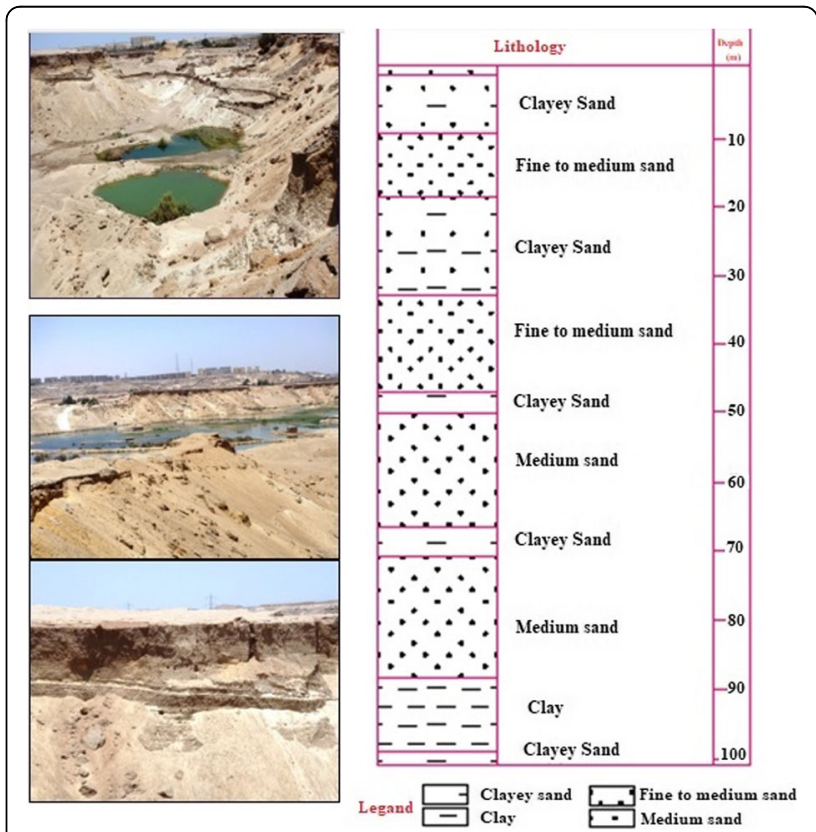

Fig. 14 Lithology of the Quaternary aquifer in the study area 


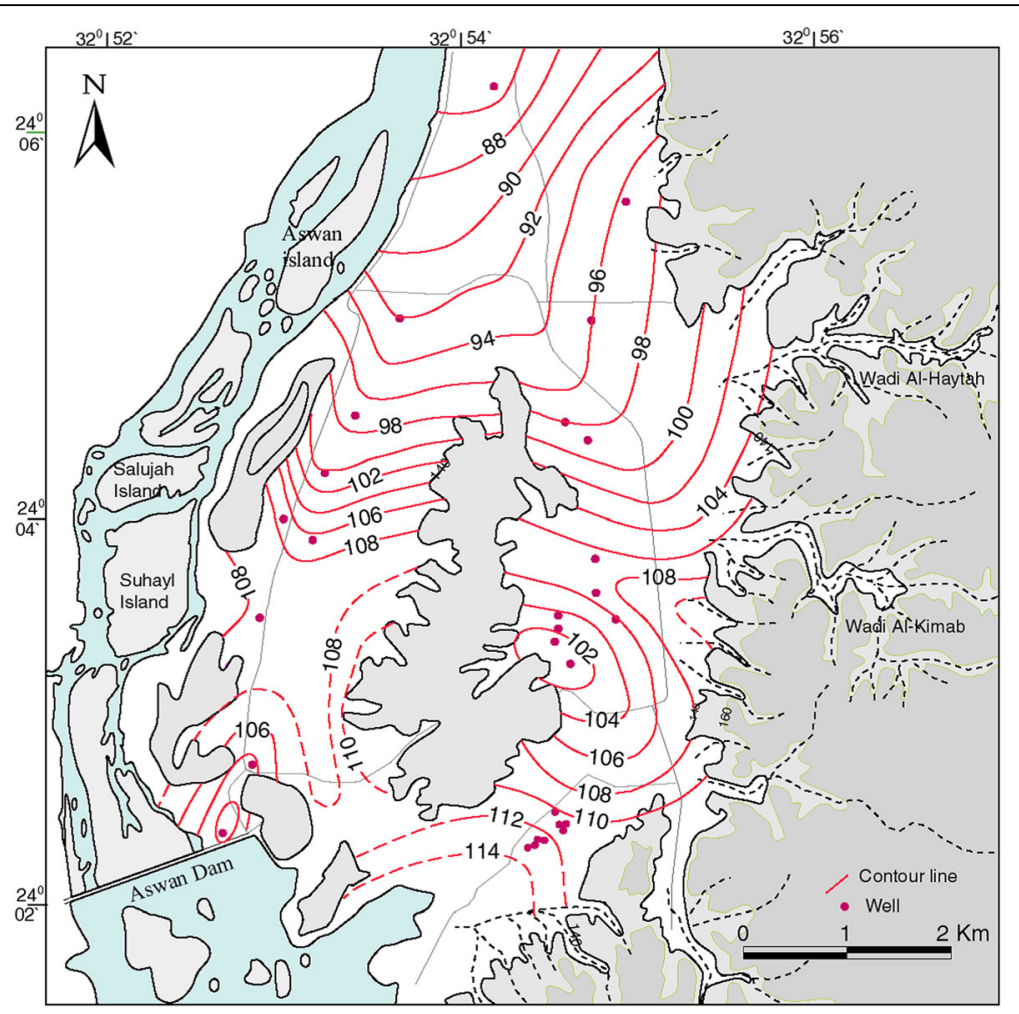

Fig. 15 Groundwater levels in the study area

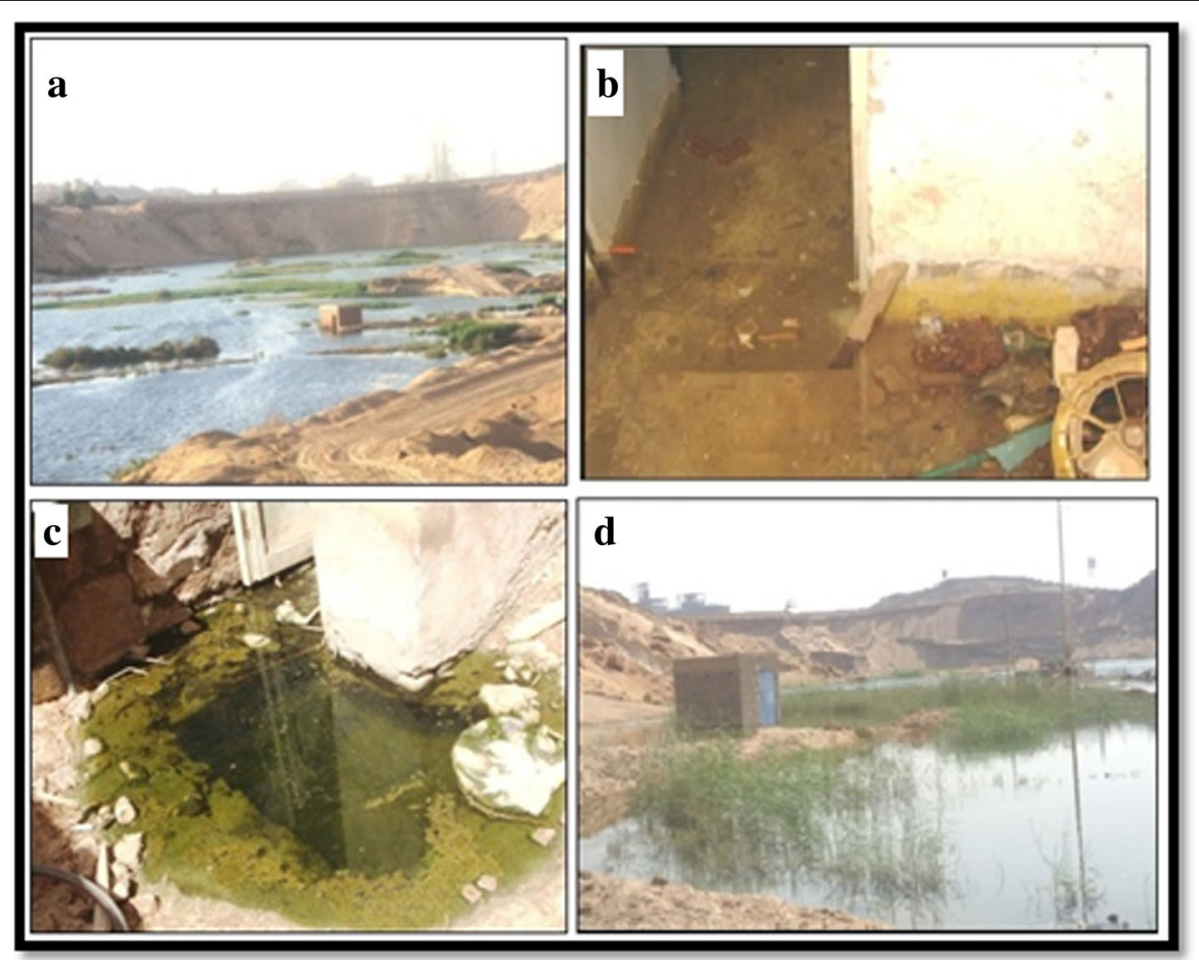

Fig. 16 Rising of the groundwater level a KhorAwada, b, c near some building and $\mathbf{d}$ sand quarry in the study area 


\section{Acknowledgements}

Not applicable

\section{Funding}

Not applicable

\section{Availability of data and materials}

All data generated or analyzed during this study are included in thismanuscript.

\section{Authors' contributions}

AF performed the chemical analyses of the groundwater and collected the groundwater samples. HM and MD studied the geology of the study area, analyzed and interpreted different satellite images, and studied the environmental impact and change detection. All authors read and approved the final manuscript.

\section{Ethics approval and consent to participate}

Not applicable.

\section{Consent for publication}

Not applicable.

\section{Competing interests}

The authors declare that they have no competing interests.

\section{Publisher's Note}

Springer Nature remains neutral with regard to jurisdictional claims in published maps and institutional affiliations.

\section{Author details}

'Department of Geology, Faculty of Science, Assiut University, Assiut, Egypt. ${ }^{2}$ National Authority for Remote Sensing and Space Sciences (NARSS), Assiut, Egypt. ${ }^{3}$ Department of Geology, Faculty of Science, New Valley Branch, Assiut University, Assiut, Egypt.

Received: 9 October 2018 Accepted: 17 January 2019

Published online: 29 January 2019

\section{References}

Attia MI (1954) Deposits in the Nile Valley and the delta. Geol Suv Egypt, Cairo 356

Collins JB, Woodcock CE (1996) An assessment of several linear change detection techniques for mapping forest mortality using multitemporal Landsat TM data. Remote Sens Environ 56:66-77

Das D (1990) Satellite remote sensing in subsurface water Targeting. American Congress on Surveying and Mapping and American Society of Photogrammerty and Remote Sensing (ACSM -ASPRS 1990)

Egyptian Geological Survey (1985) Geological map of The Western Desert, Scale 1:100,000 Cairo, Egypt

Green K, Kempka D, Lackey L (1994) Using remote sensing to detect and monitor land cover and land use change, photogrammetric. Eng Remote Sensing 60: $331-337$

Helmschor J, Fliigel WA (2002) Land use characterization and change detection analysis for hydrological model parameterization of large scale afforested areas using remote sensing. Phys Chem Earth 27:711-718

Hereher ME (2014) Environmental monitoring and change assessment of Toshka lakes in southern Egypt using remote sensing. Environ Earth Sci 73:3623-3632

Kaufman RK, Seto KC (2001) Change detection, accuracy, and bias in a sequential analysis of Landsat imagery in the Pearl River Delta, China: econometric techniques. Agric Ecosystems Environ 85:95-105

Nagy GG, Toloba J, 1971 Procedural questions in signature analysis" proc. 7.th Int. Symp. On Remote sensing environment, Ann. Arbor, Michigan 1387-1401.

Ola H, Hay GJ (2003) Amultiscale object-specific approach to digital change detection. Int J Appl Earth Obs Geoinf 4:311-327

RIGW (1988) Hydrogeological Map of Egypt. First Edition, Scale 1:2000,000, Research Institute for Groundwater, Ministry of Public Works and Water Resources, Cairo, Egypt

Ridd MK, Liu J (1998) A comparison of four algorithms for change detection in an urban environment. Remote Sens Environ 63:95-100
Singh A (1989) Digital change detection techniques using remotely sensed data. Int J Remote Sensing 10:989-1003

Yuan F, Sawaya KE, Loeffelholz BC, Bauer ME (2005) Land cover classification and change analysis of the Twin Cities (Minnesota) Metropolitan Area by multitemporal Landsat remote sensing. Remote Sens Environ 98:317-332

\section{Submit your manuscript to a SpringerOpen ${ }^{\circ}$ journal and benefit from:}

- Convenient online submission

- Rigorous peer review

- Open access: articles freely available online

High visibility within the field

- Retaining the copyright to your article

Submit your next manuscript at $\boldsymbol{\nabla}$ springeropen.com 